Удк: 343.2

\title{
ПРАВОВА ПРИРОДА ОБМЕЖУВАЛЬНИХ ЗАХОДІВ У КРИМІНАЛЬНОМУ ПРАВІ УКРАЇНИ
}

\author{
Ю. Пліш \\ Львівський національний університет імені Івана Франка, \\ вул. Університетська, 1, Львів, Україна, 79000, \\ e-mail: yulia.plish0311@gmail.com
}

Вітчизняне кримінальне право перебуває у постійній динаміці, тобто норми чинного законодавства вдосконалюють, запроваджують зовсім нові, раніше невідомі, кримінальноправові категорії, враховують і досліджують рекомендації міжнародних інституцій та інше. Не виняток у цьому процесі, і розділ XIII-1 Загальної частини КК України, в якому регламентовані обмежувальні заходи (ці положення набули чинності 11 січня 2019 року).

Відтак, у науковій статті висвітлено розуміння правової природи обмежувальних заходів. Проаналізовано поняття «кримінально-правові наслідки» та їх реалізацію через заходи кримінально-правового впливу. Подано авторську класифікацію кримінально-правових заходів та доведено, що обмежувальні заходи належать до заходів безпеки у кримінальному праві України. Аргументовано, що впровадження інституту заходів безпеки $є$ потребою сьогодення. Наголошено, що існування та реалізація обмежувальних заходів у межах кримінального права є доцільним та необхідним механізмом протидії злочинності. Узагальнено ознаки обмежувальних заходів, які вичерпно висвітлюють їх правову природу.

Ключові слова: кримінальне законодавство, кримінально-правовий вплив, кримінально-правові заходи, заходи безпеки.

DOI: http://dx.doi.org/10.30970/vla.2020.70.229

Сьогодні кримінальному праву України притаманна тенденція до розширення кола кримінально-правових наслідків, які застосовують до особи, котра вчинила суспільно небезпечне діяння, передбачене Особливою частиною Кримінального кодексу України (далі - КК України). Законом України (далі - ЗУ) «Про внесення змін до Кримінального та Кримінального процесуального кодексів України 3 метою реалізації положень Конвенції Ради Свропи про запобігання насильству стосовно жінок і домашньому насильству та боротьбу з цими явищами» від 6 грудня 2017 року [3] Загальна частина КК України доповнена розділом XIII-1 «Обмежувальні заходи» (ці положення набули чинності 11 січня 2019 року) [1]. Такі положення у вітчизняному кримінальному законодавстві регламентовано вперше. У зв'язку з новизною цих приписів закону про кримінальну відповідальність існує обгрунтована потреба у дослідженні, перш за все, правової природи обмежувальних заходів, яка стане підгрунтям для майбутніх наукових досліджень.

У сучасному світі актуальною $є$ концепція дуалізму покарань та інших заходів кримінально-правового впливу. Зазначений дуалістичний підхід, який отримав назву «двоколійності» заходів кримінально-правового впливу, застосовано у кримінальному законодавстві більшості демократичних держав, зокрема, Республіки Польща, Китайської Народної Республіки, Республіки Естонія, Франції, Федеративної Республіки Німеччина, Литовської Республіки, Республіки Молдова та інших. Суть його у тому, що одночасно застосовують покарання та інші кримінально-правові заходи, які у кожному випадку мають спеціальну мету, наприклад,

(C) Пліш Ю., 2020 
вони можуть бути спрямовані на усунення небезпеки, запобігання вчинення особою суспільно небезпечних діянь, передбачених у Особливій частині КК України, виконання особою певних дій, дотримання спеціальних заборон тощо.

Цікавим є дослідження М. І. Хавронюка, який виявив послідовно історичний прогрес кримінального законодавства у ретроспективі в частині кримінально-правових заходів, що застосовують до особи, яка вчинила кримінальне правопорушення - це виглядає так:

- відмова від кваліфікованих (жорстоких) видів смертної кари, калічницьких та інших тілесних покарань, каторжних робіт;

- значне витіснення тюремного ув'язнення штрафом та іншими майновими покараннями, обов'язковими роботами;

- введення пробації, інших видів так званого умовного покарання;

- вилучення неповнолітніх зі сфери загального кримінального права;

- загальна заборона смертної кари і будь-яких покарань, які можуть завдати фізичних страждань або принизити людську гідність;

- все більш широкий спектр покарань, альтернативних позбавленню волі;

- трансформація окремих видів покарань в інші примусові заходи, які не $\epsilon$ покаранням [10, с. 6].

Відтак, можна констатувати, що всі суспільні відносини є динамічними, сфери людського життя розвиваються, тому і погляди на систему заходів кримінально-правового впливу змінюються. Е. Феррі, керуючись ідеєю, що, окрім покарання, необхідно шукати нові заходи впливу, які були б спроможні захистити суспільство від злочинних посягань, розробив концепцію соціального захисту. Відповідно до неї потенціал суспільства у протидії злочинності має бути спрямованим на захист суспільства від соціально небезпечних елементів - теорію так званих кримінальних заступників, задля чого суспільство має розробити низку заходів для нейтралізації осіб, що перебувають у «небезпечному стані», тобто індивідів, які є небезпечними для суспільства [9, с. 214].

3'ясування правової природи обмежувальних заходів варто розпочати 3 розмежування понять «кримінально-правовий вплив» та «кримінально-правовий захід», оскільки і до сьогодні в юридичній літературі не вироблено єдиного підходу. Вважаю, що вони співвідносяться як рід та вид, оскільки категорія кримінально-правовий вплив є комплексним та складним феноменом і відповідно охоплює не лише заходи кримінально-правового характеру, а й наявність певної ідеології, формування кримінально-правової політики у державі, існування закону про кримінальну відповідальність тощо.

Щодо кримінально-правових заходів протидії злочинності, то їхня система складається 3 покарання, заходів безпеки, заходів стимулювання (заохочення), заходів відновлення матеріальних (економічних) правовідносин. Підтвердженням цьому є частина третя статті 3 КК України, де передбачено, що злочинність діяння, а також його караність та інші кримінально-правові наслідки визначаються тільки цим Кодексом [1], на основі цього положення можна констатувати, що законодавцем передбачено низку кримінально-правових наслідків, які можуть бути одночасно чи альтернативно застосовані до особи, яка вчинила суспільно небезпечне діяння.

Кримінально-правові наслідки у кримінальному праві України реалізуються через заходи кримінально-правового характеру, на мою думку, їх варто розглянути крізь призму зв'язку зі суспільною небезпечністю, яка означає, що певна поведінка особи заподіяла істотну шкоду іншій особі, суспільству чи державі або могла заподіяти таку шкоду. Отже, застосування заходів кримінально-правового характеру можна класифікувати за критерієм підстави їх накладення та виділити: 1) за злочин (настає 
Ю. Пліш

ISSN 0136-8168. Вісник Львівського університету. Серія юридична. 2020. Випуск 70

кримінальна відповідальність); 2) за суспільно небезпечні діяння, які не є злочином (наприклад, примусові заходи медичного характеру, примусові заходи виховного характеру тощо). Проте, цей поділ не завжди може бути застосований, наприклад, окремі заходи безпеки неможливо поділити, оскільки вони можуть застосовуватися як до першої, так і до другої категорії суспільно небезпечних діянь.

У контексті розгляду та дослідження інституту обмежувальних заходів необхідно виявити сутність заходів безпеки як різновиду заходів кримінально-правового характеру. С. С. Яценко зазначив, що заходи безпеки - це різновид реакції держави на діяння, яке $\epsilon$ суспільно небезпечним. В українському кримінальному праві заходи безпеки розглядають як дії «обмежувального характеру, що застосовуються від імені держави за мотивованим рішенням суду до особи, яка вчинила суспільно небезпечне діяння, передбачене кримінальним законом, і становить небезпеку для суспільства, спрямовані на попередження і припинення порушення права або на припинення дій, що порушують (або здатні порушити) інтереси інших осіб, суспільства, держави, усунення передумов криміногенної ситуації, попередження вчинення такою особою нових суспільно небезпечних діянь, а також на захист прав та інтересів суспільства та держави від суспільно небезпечних посягань з боку такої особи» [12].

Відтак, застосування заходів безпеки є дієвим кроком у запобіганні та нейтралізації криміногенної ситуації. Вони є переважно превентивними, попереджувальними, а підставою їх застосування є вчинене суспільно небезпечне діяння. Вид та строк, на який може бути призначено захід безпеки визначають у кожному випадку індивідуально, опираючись на вчинене кримінальне правопорушення та особу, що вчинила суспільно небезпечне діяння.

Варто також зауважити, що інститут заходів безпеки у кримінальному праві України пов'язаний із поняттям «особа, що перебуває у небезпечному стані». Сьогодні існування цих двох правових категорій існує лише на теоретичному рівні, проте вже ближчим часом можна спрогнозувати суттєві зміни щодо вищесказаного. Президент України В. О. Зеленський скористався своїм правом законодавчої ініціативи та подав до Верховної Ради України Проєкт Закону про внесення змін до Кримінального кодексу України щодо відповідальності за злочини, вчинені злочинною спільнотою, в якому передбачена регламентація положень щодо «крадія в законі», вказаний законопроєкт передано на повторне друге читання [4]. Таке словосполучення вже наявне у законі про кримінальну відповідальність нашої держави, але під впливом певних соціальних чинників законодавець відмовився від такої термінології. Відтак, варто з особливою обережністю ставитися до впровадження цього інституту у кримінальне законодавство України. Важливо пам'ятати, що у частині першій статті 2 КК України вказано, що підставою кримінальної відповідальності є вчинення особою суспільно небезпечного діяння, яке містить склад злочину, передбаченого цим Кодексом [1], отже, ключовою складовою тут виступає діяння (дія або бездіяльність) особи, але аж ніяк не ії статус чи стан.

Підсумовуючи вищенаведене, не викликає заперечень потреба регламентації у законодавстві інституту заходів безпеки і відповідно поняття «крадій у законі», але активація цього статусу у правовому розумінні можлива лише за умови вчинення цією особою суспільно небезпечного діяння. Цей досвід існує й у деяких зарубіжних державах, наприклад, Франція, Італійська Республіка, Королівство Іспанія, Республіка Польща, Грузія та інші визнають правовою підставою застосування заходів безпеки саме «суспільно небезпечний стан особи», тобто наявність індивіда, який є небезпечним для суспільства. Більше того, ООН, Рада Європи, Європейський суд 3 прав людини (далі - ЄСПЛ) (рішення «Ашларба проти Грузії» 
(«Ashlarba v. Georgia») [7] та інші міжнародні інституції підтримують адекватні прагнення держав до запровадження максимально ефективних механізмів протидії злочинності. Підтвердженням того, що в Україні також необхідним є впровадження інститутів заходів безпеки та «крадія в законі» виявляється у наявності специфічної мети заходів безпеки - захист від загрози, що викликана чи може бути викликана в майбутньому (функція превенції) суспільно небезпечним діянням особи, яка є небезпечною щодо інших осіб, суспільства та/або держави.

Отже, з моменту регламентації обмежувальних заходів у КК України вони набули статусу заходів кримінально-правового впливу, за правовою природою вони відмінні від покарання, адже хоча й обумовлені вчиненням злочину, однак не виступають формою реалізації кримінальної відповідальності. Щоб чітко розмежувати обмежувальні заходи та покарання, необхідно виявити мету призначення кожного з інститутів. Щодо покарання, то варто звернутися до частини другої статті 50 КК України, де передбачене покарання має на меті не тільки кару, а й виправлення засуджених, а також запобігання вчиненню нових злочинів як засудженими, так і іншими особами [1]. За допомогою методів аналізу та синтезу розділу XIII-1 КК України видається за можливе розкрити мету обмежувальних заходів у межах кримінального права, зокрема, убезпечення потерпілого від особи, що вчинила суспільно небезпечне діяння, захист від вчинення суспільно небезпечних дій щодо потерпілого у майбутньому, мінімізація взаємодії між особою, що перебуває у небезпечному стані, 3 потерпілим, якщо така несе істотні ризики. Відтак, не викликає сумніву належність обмежувальних заходів до інститутів матеріального кримінального права.

Проте $\epsilon$ і протилежна позиція, викладена у зауваженні до проєкту закону, на підставі якого внесені зміни до КК України в частині регламентації інституту обмежувальних заходів. Отож, стверджено, що обмежувальні заходи, передбачені у ст. 91-1 КК України не належать до заходів кримінально-правового впливу, оскільки їх застосування спрямоване не на реалізацію індивідуальної превенції, а фактично є заходами адміністративно-правового впливу, що мають на меті убезпечити жертву насильства в сім'ї від правопорушника або його впливу, тобто запобігти продовженню чи повторенню такого насильства [3]. 3 цим твердженням складно погодитися, оскільки у ЗУ «Про запобігання та протидію домашньому насильству» [6] і справді передбачена видача уповноваженими органами термінового заборонного припису та обмежувального припису, однак у першому випадку це здійснюють органи Національної поліції України у разі існування безпосередньої загрози життю чи здоров'ю постраждалої особи з метою негайного припинення домашнього насильства, недопущення його продовження чи повторного вчинення, тобто факт вчинення кримінального правопорушення ще недоведений, а щодо обмежувального припису, то його видає суд згідно 3 положеннями Цивільного процесуального кодексу України [11]. Більше того, Кримінальний процесуальний кодекс України (далі - КПК України) також містить схожий інститут, який навіть таку ж назву носить (частина шість статті 194 КПК України) [2], але в цьому випадку обмежувальні заходи дотичні до запобіжних заходів у кримінальному провадженні, тобто їх застосовують до моменту винесення рішення суду у конкретному кримінальному провадженні, а згідно з частиною першою статті 91-1 КК України: «одночасно з призначенням покарання, не пов'язаного 3 позбавленням волі, або звільненням з підстав, передбачених цим Кодексом, від кримінальної відповідальності чи покарання, суд може застосувати до особи, яка вчинила домашне насильство, один або декілька обмежувальних заходів» [1]. 
Ю. Пліш

ISSN 0136-8168. Вісник Львівського університету. Серія юридична. 2020. Випуск 70

Окрім вищенаведеного, на важливу роль обмежувальних заходів саме як заходів кримінально-правового характеру звертає увагу і ЄСПЛ. Зокрема, у рішенні «Опуз проти Туреччини» («Opuz v. Turкеу») Суд вказує, що насильство в сім’ї не є приватною чи сімейною справою, а є питанням, що торкається суспільних інтересів, що своєю чергою вимагає ефективних дій з боку держави. Судом зазначено, що застосування лише кримінального покарання стосовно винного не дає адекватного стримуючого ефекту, здатного забезпечити ефективне запобігання насильству щодо жінок, оскільки такого ефекту можна досягти лише у поєднанні кримінальної відповідальності щодо винного як реакції органів влади на факт умисного вбивства 3 іншими заходами кримінально-правового характеру. Реалізація лише покарання щодо винного, причому занадто м'якого, свідчить про певну терпимість держави до його діянь. У підсумку вказано, що органи державної влади не виконали свого обов'язку вжити заходів на захист заявниці, щоб утворити дієвий запобіжний механізм на забезпечення іiі фізичної недоторканності від серйозних загроз із боку іiі колишнього чоловіка [8]. Очевидно, що здійснення такого захисту не $є$ можливим без реалізації безпосередньо обмежувальних заходів кримінально-правового впливу.

Отже, варто виділити ознаки обмежувальних заходів, що й визначатимуть їх правову природу: 1) вони є заходом державного примусу, оскільки застосовуються до особи уповноваженими на те суб'єктом; 2) обмежувальні заходи передбачені ст. 91-1 КК України і належать до заходів кримінально-правового впливу; 3) мають додатковий характер, належать до категорії інших заходів кримінально-правового характеру, а саме заходів безпеки, оскільки застосовуються поряд із покаранням (окрім покарань, пов'язаних із позбавленням волі).

Обмежувальні заходи для вітчизняного кримінального права $\epsilon$ новими та малодослідженими. Аналіз цих приписів закону варто було розпочати з правової природи, оскільки саме вона виявить сутність останніх. Відтак, у системі заходів кримінального правового впливу обмежувальні заходи варто віднести до інших заходів кримінально-правового характеру, заходів безпеки. Законодавець інститут обмежувальних заходів виділив у окремий розділ Загальної частини КК України, проте, вважаю, що таке розміщення є невиправданим і призводить до плутанини, ст. 91-1 КК України «Обмежувальні заходи, що застосовуються до осіб, які вчинили домашнє насильство» потрібно помістити у розділ XIV Загальної частини КК України «Інші заходи кримінально-правового характеру» [1].

\section{Список використаних джерел}

1. Кримінальний кодекс України від 05.04.2001 р. № 2341-III. Редакція від 16.01.2020 р. // Офіційний вісник України. 2001. № 21. С. 1. Ст. 920.

2. Кримінальний процесуальний кодекс України від 13.04.2012 p. № 4651-VI. Редакція від 13.02.2020 р. // Офіційний вісник України. 2012. № 37. С. 11. Ст. 1370.

3. Про внесення змін до деяких законів України у зв'язку з ратифікацією Конвенції Ради Європи про запобігання насильству стосовно жінок і домашньому насильству та боротьбу 3 цими явищами : Зауваження до проекту Закону України № 4952 від 12.07.2016 р. № 2227VIII. URL: http://w1.c1.rada.gov.ua/pls/zweb2/webproc4_1?pf3511=59648

4. Про внесення змін до деяких законодавчих актів України щодо відповідальності за злочини, вчинені злочинною спільнотою : Проект Закону України № 2513 від 02.12.2019 p. URL: http://w1.c1.rada.gov.ua/pls/ zweb2/webproc4_1?pf3511=67506

5. Про внесення змін до Кримінального та Кримінального процесуального кодексів України з метою реалізації положень Конвенції Ради Європи про запобігання насильству стосовно жінок і домашньому насильству та боротьбу з цими явищами : Закон України від 06.12.2017 p. № 2227-VIII. URL: https://zakon.rada.gov.ua/laws/show/2227-19 
6. Про запобігання та протидію домашньому насильству : Закон України від 07.12.2017 p. № 2229-VIII. Редакція від 01.01.2020 // Офіційний вісник України. 2018. № 6. С. 16. Ст. 245.

7. Рішення Європейського суду з прав людини в справі «Ашларба проти Грузії»: заява № 45554/08 від 15.07.2014 p. URL: https://hudoc.echr.coe.int/fre\#\{\%22itemid\%22:[\%22001-145572\%22]\}

8. Рішення Європейського суду з прав людини в справі «Опуз проти Туреччини»: заява № 33401/02 від 09.06.2009 p. URL: http://hudoc.echr.coe.int/rus?i=001-119720

9. Ферри Э. Уголовная социология / пер. с 5-го фр. изд. 1905 г. ; под ред. и с предисл. С. В. Познышева ; пер. О. В. Познышева. Москва : В. М. Саблин, 1908. 615 с.

10. Хавронюк M. Заходи кримінально-правового впливу: які вони бувають // Юридичний вісник України : все про закони - в одній газеті: загальнонаціональна правова газета. Київ, 2013. 25-31 травня (№ 21). С. 6-7.

11. Цивільний процесуальний кодекс України від 18.03.2004 р. № 1618-IV // Офіційний вісник України. 2004. № 16. С. 11. Ст. 1088.

12. Яценко C. Заходи безпеки у кримінальному праві: порівняльно-правовий огляд // Юридична Україна : щомісячний науковий журнал / Київ. регіон. центр Нац. акад. правових наук України ; Н.-д. ін-т приватного права і підприємництва ім. акад. Ф. Г. Бурчака Нац. акад. правових наук ; ТОВ “Юрінком Інтер” ; редкол. : О. Д. Крупчан, В. В. Коваленко, В. С. Ковальський [та ін.]. Київ, 2016. № 9/10 (165/166). С. 28-35.

\section{References}

1. Kryminal'nyj kodeks Ukrainy vid 05.04.2001. № 2341-III. Redaktsiia vid 16.01.2020. (2001). Ofitsijnyj visnyk Ukrainy, № 21. Stor. 1. St. 920.

2. Kryminal'nyy protsesual'nyy kodeks Ukrayiny vid 13.04.2012. № 4651-VI. Redaktsiia vid 13.02.2020. (2012). Ofitsijnyj visnyk Ukrainy, № 37. Stor. 11. St. 1370.

3. Pro vnesennia zmin do deiakykh zakoniv Ukrainy u zv'iazku z ratyfikatsiieiu Konventsii Rady Yevropy pro zapobihannia nasyl'stvu stosovno zhinok i domashn'omu nasyl'stvu ta borot'bu z tsymy iavyschamy: Zauvazhennia do proektu Zakonu Ukrainy № 4952 vid 12.07.2016. № 2227-VIII. Retrieved from http://w1.c1.rada.gov.ua/pls/zweb2/webproc4_1?pf3511=67506

4. Pro vnesennia zmin do deiakykh zakonodavchykh aktiv Ukrainy schodo vidpovidal'nosti za zlochyny, vchyneni zlochynnoiu spil'notoiu: Proekt Zakonu Ukrainy № 2513 vid 02.12.2019. Retrieved from https://zakon.rada.gov.ua/laws/show/2227-19

5. Pro vnesennia zmin do Kryminal'noho ta Kryminal'noho protsesual'noho kodeksiv Ukrainy z metoiu realizatsii polozhen' Konventsii Rady Yevropy pro zapobihannia nasyl'stvu stosovno zhinok $i$ domashn'omu nasyl'stvu ta borot'bu $z$ tsymy iavyschamy: Zakon Ukrainy vid 06.12.2017 № 2227-VIII. Retrieved from https://zakon.rada.gov.ua/laws/show/2227-19

6. Pro zapobihannia ta protydiiu domashn'omu nasyl'stvu: Zakon Ukrainy vid 07.12.2017. № 2229VIII. Redaktsiia vid 01.01.2020. (2018). Ofitsijnyj visnyk Ukrainy, № 6. Stor. 16. St. 245.

7. Case of Ashlarba v. Georgia: № 45554/08 from 15.07.2014. Retrieved from https://hudoc.echr.coe.int/fre\#\{\%22itemid\%22:[\%22001-145572\%22]\}.

8. Case of Opuz v. Turkey: № 33401/02 from 09.06.2009. Retrieved from http://hudoc.echr.coe.int/rus?i=001-119720.

9. Ferri, E. (1908). Ugolovnaya sotsiologiya: Per. s 5-go fr. izd. 1905 / Pod red. i s predisl. S. V. Poznyisheva; Per. O. V. Poznyisheva. Moscow.

10. Tsyvil'nyj protsesual'nyj kodeks Ukrainy vid 18.03.2004. № 1618-IV. (2004). Ofitsijnyj visnyk Ukrainy, № 16. Stor. 11. St. 1088.

11. Khavroniuk, M. (2013). Zakhody kryminal'no-pravovoho vplyvu: iaki vony buvaiut'. In: Yurydychnyj visnyk Ukrainy: vse pro zakony - v odnij hazeti: zahal'nonatsional'na pravova hazeta. Kyiv, № 21.

12. Yatsenko, S. (2016) Zakhody bezpeky u kryminal'nomu pravi: porivnial'no-pravovyj ohliad. In: Yurydychna Ukraina: schomisiachnyj naukovyj zhurnal. Kyiv, № 9/10 (165/166), 28-35. 


\title{
LEGAL NATURE OF RESTRICTIVE MEASURES IN CRIMINAL LAW OF UKRAINE
}

\author{
Y. Plish \\ Ivan Franko National University of Lviv, \\ 1, Universytetska Str., Lviv, Ukraine, 79000, \\ e-mail: yulia.plish0311@gmail.com
}

Domestic criminal law is being in constant dynamics, so it means that the norms of the current legislation are being improved, new, previously unknown, criminal-legal categories are being introduced, recommendations of international institutions are taken into account, etc. Not an exception in this process is Chapter XIII-1 of the General Part of the Criminal Code of Ukraine, which regulates restrictive measures (these provisions came into force on January 11, 2019).

For the complete and comprehensive study of restrictive measures, the scientific interest is caused primarily by their legal nature. Restrictive measures are in the system of criminal-legal consequences applied to the person who committed a socially dangerous act. These criminallegal consequences are applied through criminal-legal measures to counteract crimes. The system of criminal-legal measures can be summarized by categories: punishment, security measures, incentives (encouragement), measures of restoration of material (economic) relationships. In the context of considering the legal nature of restrictive measures, it is necessary to identify the nature of security measures, since the two concepts are linked to each other, moreover, the restrictive measures are one of the types of security measures. Security measures are mostly preventive and warning, and the ground for their application is a socially dangerous act. The type and term, for which a security measure can be assigned, is determined in each case individually based on the criminal offense and the person who committed the socially dangerous act. Today, the institution of security measures exists only at the theoretical level, but due to the recent reform of the criminal legislation, radical changes and corresponding regulation of this concept in the Criminal Code of Ukraine can be expected in the near future.

Therefore, starting from the moment of the restrictive measures regulation in the Criminal Code of Ukraine, they have acquired the status of criminal-legal measures. Restrictive measures have a specific purpose - to protect the victim from a person who has committed a socially dangerous act, to protect against committing a socially dangerous act in relation to the victim in the future, to minimize the interaction between the person, who is in a dangerous state, and the victim, if such has the significant risks.

Based on the above, it is necessary to distinguish the features of restrictive measures that will determine their legal nature: 1) they are the measures of governmental constraint, since they are applied to someone who has a legal right; 2) restrictive measures are regulated in Article 91-1 of the Criminal Code of Ukraine and refer to the measures of criminal-legal influence; 3) have a supplementary nature and belong to the category of other criminal-legal measures, specifically, security measures, since they are applied in addition to the punishment (except for the penalties related to imprisonment).

Keywords: criminal legislation, criminal-legal influence, criminal-legal measures, security measures. 